\title{
The physiological and behavioral responses of steers to gaseous ammonia in simulated long-distance transport by ship
}

\author{
C. J. C. Phillips, ${ }^{* 1}$ M. K. Pines, ${ }^{*}$ M. Latter, ${ }^{*}$ T. Muller ${ }^{*}+$ J. C. Petherick, $\dagger^{*}$ \\ S. T. Norman, * and J. B. Gaughan $\ddagger$ \\ *Centre for Animal Welfare and Ethics, School of Veterinary Sciences, The University of Queensland, Gatton, \\ Queensland 4343, Australia; †Agri-Science Queensland, Rockhampton, Queensland 4702, Australia; \\ and $\ddagger$ School of Animal Studies, The University of Queensland, Gatton, Queensland 4343, Australia
}

\begin{abstract}
Ammonia can accumulate in highdensity cattle accommodation during live export shipments and potentially threaten the health and welfare of the animals. The effects of $4 \mathrm{NH}_{3}$ concentrations, control $(<6), 11,23$, and $34 \mathrm{mg} / \mathrm{m}^{3}$, on the physiology and behavior of steers were recorded. The animals were held for $12 \mathrm{~d}$ under a microclimate and stocking density similar to shipboard conditions experienced on voyages from Australia to the Middle East during the northern hemispheric summer. In bronchoalveolar lavage samples, ammonia increased $(P<0.05)$ macrophage activity in proportion to $\mathrm{NH}_{3}$ concentration and increased $(P<0.05)$ neutrophil percentage at 23
\end{abstract}

and $34 \mathrm{mg} / \mathrm{m}^{3}$, indicating active pulmonary inflammation. Ammonia also increased $(P<0.05)$ lacrimation, nasal secretions, and coughing, particularly at $34 \mathrm{mg} /$ $\mathrm{m}^{3}$, indicating that the $\mathrm{NH}_{3}$ was irritating the mucous membranes of the eyes, nasal cavity, and respiratory tract. Ammonia had no effect $(P>0.05)$ on hematological variables or BW. Twenty-eight days after exposure to $\mathrm{NH}_{3}$, the pulmonary macrophage activity and neutrophil concentrations of the steers had returned to normal. It was concluded that ammonia concentrations of 23 and $34 \mathrm{mg} / \mathrm{m}^{3}$ induced temporary inflammatory responses, which indicate an adverse effect on the welfare of steers.

Key words: ammonia, cattle, live export, respiratory toxicology, steer

(C)2010 American Society of Animal Science. All rights reserved.

J. Anim. Sci. 2010. 88:3579-3589

doi:10.2527/jas.2010-3089

\section{INTRODUCTION}

Worldwide live export shipments convey animals worth more than $\$ 10$ billion annually, increasing by $4 \%$ per year (Phillips, 2008). Australia is the largest exporting country, sending cattle and sheep mainly to the Middle East and Asia on journeys typically lasting 7 to $15 \mathrm{~d}$. Ammonia accumulates at increased cattle stocking densities and potentially could affect the health and welfare of cattle during these shipments. A survey of 6 voyages between Australia and the Middle East indicated that typical $\mathrm{NH}_{3}$ concentrations below decks were $11 \mathrm{mg} / \mathrm{m}^{3}$ with readings commonly reaching 15 to 23 $\mathrm{mg} / \mathrm{m}^{3}$ (MAMIC Pty, 2001). There is no universally applied maximum ammonia concentration for live export shipments, although Tudor et al. (2003) recommended that a time-weighted average (TWA; mean value of exposure over the course of an 8-h work shift) of 15 $\mathrm{mg} / \mathrm{m}^{3}$ of $\mathrm{NH}_{3}$ should be adopted, based on preliminary

\footnotetext{
${ }^{1}$ Corresponding author: c.phillips@uq.edu.au

Received April 15, 2010.

Accepted July 7, 2010.
}

lung studies using bronchoalveolar lavages (BAL). They observed increases in white blood cell counts and mononucleated cell counts in BAL samples from cattle after $9 \mathrm{~d}$ of exposure to approximately $15 \mathrm{mg} / \mathrm{m}^{3}$ of $\mathrm{NH}_{3}$. Costa et al. (2003) concluded from a review of the literature that a TWA of $19 \mathrm{mg} / \mathrm{m}^{3}$ would be an appropriate maximum concentration for livestock shipments. However, they also concluded from their investigations of hematological immunocompetence that there were initial clinical signs of pulmonary inflammation at 17 $\mathrm{mg} / \mathrm{m}^{3}$ of gaseous $\mathrm{NH}_{3}$. They acknowledged that more information on the impact of long-term exposure was necessary before standards could be established.

Although there is limited evidence of the effects of exposure of cattle to $\mathrm{NH}_{3}$, several studies have been conducted with pigs and poultry under intensive housing conditions. In exposure trials lasting 1 to $2 \mathrm{wk}$, both pigs and poultry showed a preference for fresh air compared with air with $8 \mathrm{mg} / \mathrm{m}^{3}$ of $\mathrm{NH}_{3}$ (Wathes et al., 2002), and for poultry there is evidence that welfare is adversely affected by at or below $19 \mathrm{mg} / \mathrm{m}^{3}$ of $\mathrm{NH}_{3}$ (Kristensen et al., 2000; Kristensen and Wathes, 2000). However, long-term exposure of animals to $\mathrm{NH}_{3}$ could reduce their aversion through adaptation. Humans 
Table 1. Allocation of control (Con), low, medium (Med), and high ammonia treatments to the 2 experimental chambers over the six 12 -d periods in a balanced incomplete-block design

\begin{tabular}{lll}
\hline \hline Period & Chamber 1 & Chamber 2 \\
\hline 1 & Low & Con \\
2 & Med & Low \\
3 & High & Con \\
4 & Med & High \\
5 & High & Low \\
6 & Con & Med \\
\hline
\end{tabular}

working persistently in environments with increased odors often show a reduction in responsiveness to the odor (Harada et al., 1983; Schiffman, 1998). Reduced olfactory acuity has also been reported in pigs exposed to $30 \mathrm{mg} / \mathrm{m}^{3}$ of $\mathrm{NH}_{3}$ (Jones et al., 2001), but in humans, effects of $\mathrm{NH}_{3}$ on olfaction are not conclusive (Holness et al., 1989). In simulated ship journeys, there was no evidence of habituation or sensitization to 34 $\mathrm{mg} / \mathrm{m}^{3}$ of $\mathrm{NH}_{3}$ in sheep (C. J. C. Phillips, M. K. Pines, and T. Muller, unpublished data).

The aim of this study was to determine the maximum concentration of $\mathrm{NH}_{3}$ to which live export cattle can be consistently exposed to maintain good health and welfare.

\section{MATERIALS AND METHODS}

\section{Location}

The study was conducted at the CSIRO Rendel Laboratories, Rockhampton, Australia (23.4 $\left.\mathrm{S} ; 150.5^{\circ} \mathrm{E}\right)$ with the approval of the CSIRO Animal Ethics Committee.

\section{Animals and Housing}

Seventy-two Brahman $\times$ Charolais steers approximately 18 mo of age (mean BW $413 \pm 5 \mathrm{~kg}$ ), typical of the class of cattle exported by ship from Australia, were used in an 89-d study undertaken within 2 controlled climate chambers $(6.4 \mathrm{~m}$ in width $\times 9.0 \mathrm{~m}$ in length $\times 2.3 \mathrm{~m}$ in height). Within each chamber, 2 pens $(1.8 \times 2.4 \mathrm{~m})$ were used to hold 3 steers each at a stocking density of $1.45 \mathrm{~m}^{2} /$ steer. A feed trough and a water trough were fixed to the inside of each pen, occupying $0.9 \mathrm{~m}^{2}$ of the available pen space. The stocking densities were based on Australian live export guidelines (ASEL, 2006).

\section{Ammonia Treatments}

Four concentrations of $\mathrm{NH}_{3}$ were used: control (Con), cattle exposed to $<6 \mathrm{mg} / \mathrm{m}^{3}$ of gaseous $\mathrm{NH}_{3}$; low, cattle exposed to approximately $11 \mathrm{mg} / \mathrm{m}^{3}$ of gaseous $\mathrm{NH}_{3}$; medium (Med), cattle exposed to approximately 23 $\mathrm{mg} / \mathrm{m}^{3}$ of gaseous $\mathrm{NH}_{3}$; and high, cattle exposed to approximately $34 \mathrm{mg} / \mathrm{m}^{3}$ of gaseous $\mathrm{NH}_{3}$. The $4 \mathrm{NH}_{3}$ treatments were allocated to the 2 chambers so that each treatment was replicated 3 times in a balanced incomplete-block design. The replicated schedule was designed so that all pair-wise combinations of $\mathrm{NH}_{3}$ treatments were compared (Table 1). Each treatment period ran for $12 \mathrm{~d}$, which is comparable with the voyage duration experienced by live exported cattle.

A concentration of $34 \mathrm{mg} / \mathrm{m}^{3}$ of $\mathrm{NH}_{3}$ represents the greatest mean concentration in any environment that can be legally entered by humans according to National Occupational Health and Safety guidelines (NOHSC, 1995). In Con, the $\mathrm{NH}_{3}$ concentration was minimized by hosing the pen floors 3 times each day. In low, Med, and high, the feces and urine were allowed to accumulate and, where necessary, further manipulation of $\mathrm{NH}_{3}$ concentration was achieved through the hosing of the pen floor, the addition of urea to manure (in a separate section of the chamber floor, inaccessible to animals), and manual manipulation of the fresh-air fans.

\section{Climatic Conditions}

Preprogrammed concentrations for $\mathrm{O}_{2}, \mathrm{CO}_{2}$, wet bulb temperature $\left(\mathbf{T}_{\mathrm{WB}}\right)$, and dry bulb temperature $\left(\mathbf{T}_{\mathrm{DB}}\right)$ were set for each chamber. Maximum and minimum set points for each variable were established before the study and maintained throughout. An Innotech GENII Modem Interface control system (Mass Electronics, Queensland, Australia) logged climatic data and managed the climatic variables within the chambers. Wet bulb temperature, $\mathrm{T}_{\mathrm{DB}}$, and humidity $(\mathbf{R H})$ were measured using a HMW61Y Vaisala humidity and temperature transmitter (Vaisala Oyj, Vantaa, Finland; accuracy $\pm 2 \%$, and $\pm 0.1^{\circ} \mathrm{C}$, respectively, for $\mathrm{RH}$ and $\mathrm{T}_{\mathrm{WB}}$, $\mathrm{T}_{\mathrm{DB}}$ ). The $\mathrm{T}_{\mathrm{WB}}$ and $\mathrm{T}_{\mathrm{DB}}$ programmed for the climate rooms were based on shipboard values that had previously been recorded on 3 voyages: 2 from Fremantle, Western Australia, to the Middle East, and 1 from Darwin, Northern Territory, Australia, to the Middle East. Wet bulb temperature was adjusted once daily at 0500 $\mathrm{h}, \mathrm{T}_{\mathrm{DB}}$ was adjusted twice daily, at 0500 and $1700 \mathrm{~h}$, according to recorded daily fluctuations in the shipboard recorded temperatures. The target $\mathrm{T}_{\mathrm{WB}}$ at $0500 \mathrm{~h}$ for $\mathrm{d}$ 0 (day of entry to chamber) to d 12 were $23,23,24,25$, $25,26,26,27,27,27,28,28,29^{\circ} \mathrm{C}$; the $\mathrm{T}_{\mathrm{DB}}$ at $0500 \mathrm{~h}$ were $26,26,27,28,29,30,31,31,31,32,33,34,35^{\circ} \mathrm{C}$, respectively, for d 0 to 12 ; dry bulb temperature at $1700 \mathrm{~h}$ was $1^{\circ} \mathrm{C}$ less than the temperature at $0500 \mathrm{~h}$.

Carbon dioxide was measured using a Vaisala GMT220 $\mathrm{CO}_{2}$ transmitter (Vaisala Oyj; accuracy \pm 39 $\mathrm{mg} / \mathrm{m}^{3}$ ). Oxygen was measured using an AST Oxygen transmitter (Critical Environment Technologies, Delta, Canada; accuracy $\pm 0.2 \%$ ). Gaseous $\mathrm{NH}_{3}$ was manually monitored twice daily at 5 locations within each chamber (2 at standing cattle head height, 2 at lying cattle 
Table 2. Dietary composition and nutrient content

\begin{tabular}{lc}
\hline \hline Item & $\begin{array}{c}\text { Percentage } \\
\text { inclusion }\end{array}$ \\
\hline Ingredient, \% & \\
Sorghum & 20.00 \\
Copra meal & 9.00 \\
Chickpea offal & 20.00 \\
Millrun & 40.23 \\
Molasses & 3.00 \\
Limestone & 2.74 \\
Salt & 0.50 \\
Bentonite & 4.00 \\
Dicalcium phosphate & 0.30 \\
Premix ${ }^{1}$ & 0.20 \\
Rumensin ${ }^{2}$ (10\%) & 0.025 \\
Nutrient content, DM basis & \\
ME, MJ $/$ kg & 9.89 \\
CP, \% & 12.02 \\
Undegraded protein, \% & 3.73 \\
ADF, \% & 18.03 \\
NDF, \% & 35.38 \\
Crude fiber, \% & 14.76 \\
Calcium, \% & 1.19 \\
Phosphorus, \% & 0.61 \\
Chlorine, \% & 0.42 \\
Sodium, \% & 0.23 \\
\hline
\end{tabular}

${ }^{1}$ Contained (on a DM basis): 3,000 IU/g of vitamin A, $250 \mathrm{IU} / \mathrm{g}$ of vitamin $\mathrm{D}_{3}, 2,500 \mathrm{mg} / \mathrm{kg}$ of vitamin $\mathrm{E}, 7,500 \mathrm{mg} / \mathrm{kg}$ of iron, 25,000 $\mathrm{mg} / \mathrm{kg}$ of zinc, $15,000 \mathrm{mg} / \mathrm{kg}$ of magnesium, $5,000 \mathrm{mg} / \mathrm{kg}$ of copper, 50 $\mathrm{mg} / \mathrm{kg}$ of selenium, $250 \mathrm{mg} / \mathrm{kg}$ of molybdenum, 1,000 mg/ $\mathrm{kg}$ of cobalt, and $250 \mathrm{mg} / \mathrm{kg}$ of iodine.

${ }^{2}$ Provided $25 \mathrm{mg} / \mathrm{kg}$ of monensin sodium (Rumensin 100, Elanco, Sydney, Australia).

head height, and 1 at floor level) using a handheld electrochemical meter (OdaLog gas data logger, App-tek, Brendale, Australia, accuracy $\pm 4 \mathrm{mg} / \mathrm{m}^{3}$; resolution: $0.75 \mathrm{mg} / \mathrm{m}^{3}$, factory calibrated $4 \mathrm{mo}$ before the study and again during mo 2 of the study). Each chamber had its own independent air conditioning unit, and air flow rate was $1,071 \mathrm{~m}^{3} / \mathrm{h}$. Pressurized water fed through humidifiers was used to maintain the RH in each chamber. Lighting was provided $24 \mathrm{~h} / \mathrm{d}$ via 6 fluorescent lights in each chamber, replicating shipboard conditions. The concrete floors of the pens were sloped so that water and urine ran into a grated draining system positioned at the center of each chamber. The pen floors were cleaned daily at 0630,1200 , and $1830 \mathrm{~h}$, and manure build-up within the drainage system was removed by manual flushing.

\section{Experimental Protocol}

Twelve steers (4 pens of 3 animals) were used in each of the 6 replicates. The cattle were identified on their rumps and shoulders with large individual numbers. To simulate preexport assembly depot conditions, the cattle were held in separate undercover pens $(7 \mathrm{~m} \times 12$ $\mathrm{m})$ for $5 \mathrm{~d}$ before their entry into the chambers $(\mathrm{d} 0)$. During this time, they were provided with ad libitum water and fed a pelleted diet (Ridley AgriProducts, Rockhampton, Australia; Table 2), which was formulated to meet the nutritional specifications for export of cattle (ASEL, 2006).

Before entering the climate chambers, all animals were weighed and divided into 4 groups of 3 similar cattle, according to their BW. In each replicate, 2 groups were randomly assigned to the 2 pens in each chamber. On the day before the animals entered the chambers, two 2-mL blood samples (1 placed into an EDTA Vacutainer and the other into a Serum Separator Vacutainer tube) were collected via jugular venipuncture and 1 blood smear was prepared from each of 8 steers ( 2 animals per pen). At the end of the $12-d$ period, the steers were removed from the chambers and weighed and a second set of two 2-mL blood samples was collected from the same 2 steers in each pen from which preexperiment blood samples had been collected. The blood samples were collected into serum separator tubes (Becton Dickinson Vacutainers, Franklin Lakes, $\mathrm{NJ}$ ) and centrifuged at $2,140 \times g$ for $10 \mathrm{~min}$ at $4^{\circ} \mathrm{C}$, using a Beckman J6-MI instrument (Brea, CA) followed by freezing at $-20^{\circ} \mathrm{C}$ until assayed. The blood smears were stored at $4^{\circ} \mathrm{C}$. The samples were used to determine plasma cortisol using an automated chemiluminescent EIA (Immulite 1000 Cortisol kits, sensitivity $0.2 \mu \mathrm{g} / \mathrm{dL}$ detected on an Immulite 1000 Analyser, Siemens Medical Solutions Diagnostics, Gwynedd, UK; assay validated by Tripp et al., 2010), blood urea using a kinetic UV test (OSR6134, \pm 0.35 at $7.75 \mathrm{mmol} / \mathrm{L}$, Olympus AU400 Analyser, Life and Materials Science Europa GmBH, Hamburg, Germany), and a full blood count.

\section{Data Collection}

Behavioral observations were made twice daily (0500 to $0615 \mathrm{~h}$ and 1700 to $1815 \mathrm{~h}$ ). Cleaning and other husbandry tasks were avoided just before observations to prevent residual effects on the behavior of the steers. Ten minutes before data collection, the observer entered a chamber and sat quietly to allow the animals to adjust to the presence of the observer. During a recording session, each pen was observed in random order for 15 min using a continuous sampling technique. Behavioral observations were manually recorded via Observer v5.0 software (Noldus Information Technology, Wageningen, the Netherlands) to a handheld computer (iPaq, Compaq Computer Corporation, Houston, TX). The behaviors recorded were standing, lying, ruminating, feeding, drinking, coughing, teeth grinding, pawing, foot stomping, head butting (another steer), self-licking, scratching, panting, and the position of the head (up or down). Mounting, biting, swaying, pacing, vocalizing, and sneezing were also recorded but are not reported because they were rarely observed. The presence of nasal discharge, excess lacrimation (overt surplus tear production, greater than that needed to maintain a moisture film coating the eye), and any skin 
lesions were noted at each sampling session. Feed and water consumption by each pen was measured daily at $0630 \mathrm{~h}$. Feed troughs were removed temporarily for weighing feed residues, and water was measured using a flow meter positioned in the inlet pipe. The water meter was calibrated before the study.

\section{$B A L$}

After $12 \mathrm{~d}$ in the chambers, the animals were moved to a holding area and weighed, and blood was collected (see above). Those cattle from which blood samples were collected then had a BAL sample taken. Light sedation was administered to each animal (xylazine; $0.04 \mathrm{mg} / \mathrm{kg}$, Xylazil 20, Ilium Veterinary Products, Smithfield, Australia) via intravenous injection. The animals were restrained in a head-bail, and the head was tied with the nose pointing upward. A small amount of xylocaine gel (AstraZeneca, North Ryde, Australia) was applied to the end of a 10-mm, 240-cm-long, equine BAL silicone catheter (BAL240, Cook Pty. Ltd., Brisbane, Australia), which was then passed into the ventral meatus of the left nostril and advanced toward the pharynx. On contacting the pharynx, $10 \mathrm{~mL}$ of $2 \%$ lignocaine (Pfizer Pty. Ltd., Bentley, Australia) was instilled, followed by a small amount of air to ensure the lignocaine was released from the tube. Advancing the tube while simultaneously shaking the trachea to confirm the position of the tube, an endpoint was reached when it could no longer be pushed forward. The tube cuff was then filled with 5 to $10 \mathrm{~mL}$ of air to seal the lumen of the airway. One dose of $100 \mathrm{~mL}$ of sterile saline was then instilled into the tube followed by 10 to $15 \mathrm{~mL}$ of air to ensure that all of the fluid had entered the lungs. Then, using a $20-\mathrm{mL}$ syringe, suction was applied to recover as much of the infused fluid as possible, and the tube was withdrawn after deflating the cuff. A 5-mL sample of the well-mixed aspirate was stored at $4^{\circ} \mathrm{C}$. In between animals, the bore of the BAL tube was flushed with water and rinsed initially in chlorhexidine solution, then fresh water, and finally flushed with saline solution. Smears were made of all blood and BAL samples. After these procedures, all animals were turned out to a paddock.

After $28 \mathrm{~d}$ the animals were returned to the holding area. At this time they were weighed, a third set of blood samples was collected and a second set of BAL samples obtained to determine any long-term effects of exposure to gaseous $\mathrm{NH}_{3}$.

After collection, BAL samples were analyzed for the concentration of red blood cells, total nucleated cells, lymphocytes, neutrophils, other segmented leukocytes, and macrophages. Because absolute cell counts in BAL samples are not meaningful due to dilution effects and variable harvest success, relative proportions of nucleated cells within samples were determined and compared between samples of the 4 treatments. First, total nucleated cells were counted in the sample, and then a differential count divided nucleated cells into percent- age of neutrophils, lymphocytes, eosinophils, basophils, and macrophages. Macrophage activity was determined by abundance of cytoplasm and degree of cytoplasmic vacuolation and was classified as low, medium, high, and very high.

\section{Statistical Analyses}

Before analysis, all data were checked for equal variance using Levene's test and normal distribution of residuals using the Anderson-Darling test. For those data not satisfying the Levene's test, transformations were made to achieve equal variance. Coughing data were not normally distributed and were therefore analyzed using nonparametric tests (Mood's median test and Mann-Whitney test).

Hematology, BAL, and BW values for d 13 (i.e., the day on which the animals were removed from the chamber), and d 41 data were analyzed using a GLM procedure to test for effects of ammonia treatment, period, and chamber, using pens as replicates. Where no significant effects of $\mathrm{NH}_{3}$ were found, the data were collapsed and a paired $t$-test was used to determine whether there were any overall differences between preexperiment, d 13, and $28 \mathrm{~d}$ posttreatment levels. The qualitative pulmonary macrophage activity data from the BAL procedure were analyzed using the $\chi^{2}$-test. A Pearson correlation was used to determine whether there was any relationship between the measured hematological and BAL variables.

All behavior data were examined using the pen as replicate and, along with data for food and water intake, analyzed using GLM procedures to test for effects of ammonia treatment, day of experiment, period, pen, and chamber using the statistical package Minitab (State College, PA).

\section{RESULTS}

The mean $( \pm \mathrm{SEM}) \mathrm{NH}_{3}$ concentrations $\left(\mathrm{mg} / \mathrm{m}^{3}\right)$ for the 3 replicates of treatments were $2.1 \pm 0.3,3.8 \pm 0.3$, and $5.6 \pm 0.4$ for Con; $11.3 \pm 1.1,11.7 \pm 0.3$, and 12.2 \pm 0.5 for low; $18.8 \pm 2.2,22.4 \pm 0.8$, and $22.5 \pm 0.8$ for Med; and $34.9 \pm 3.8,30.1 \pm 1.1$, and $36.1 \pm 1.3$ for high.

\section{Hematology}

Ammonia treatment had no effect $(P>0.05)$ on any of the hematological variables measured in the steers immediately after they left the chambers (d-13; Table 3 ). Preexperiment concentrations and d-13 concentrations were different in the case of 8 hematological variables compared with preexperiment concentrations; there was a decrease in $\mathrm{d}-13$ concentrations of hemoglobin $(P=0.002)$, mean cell volume $(P=0.001)$, and mean corpuscular hemoglobin $(P=0.03)$ and an increase in postexperiment platelet volume $(P=0.001)$, eosinophils $(P=0.001)$, neutrophils $(P=0.02)$, total white cell count $(P=0.001)$, and monocytes $(P=0.03$; 
Figure 1). Pre- and d-13 total white cells, lymphocytes, and monocytes were slightly above the normal range, and $\mathrm{d}-13$ (d 0 postexperiment) neutrophils were also slightly above normal range, but all other variables were within normal range, as determined by The University of Queensland's Clinical Pathology Laboratory. There was no difference $(P>0.05)$ between treatments in the hematological variables $28 \mathrm{~d}$ posttreatment.

\section{$B A L$}

There was a difference $(P=0.04)$ in pulmonary macrophage activity among the $4 \mathrm{NH}_{3}$ treatments (Figure 2 ). More steers had very high macrophage activity in the high treatment $(83 \%)$ than in the Med treatment $(50 \%)$, low treatment $(45 \%)$, or Con treatment $(8 \%)$. The Con treatment had the greatest percentage of steers $(25 \%)$ with low macrophage activity, whereas the high treatment had the least $(0 \%)$. There was little difference in macrophage activity between the low and Med treatments. The pulmonary macrophage activity of the subsample of steers that were tested $28 \mathrm{~d}$ posttreatment was in all cases but 1 classified as medium, with the one exception being low.

Ammonia treatment had no effect on BAL red and nucleated cell counts (Table 4), but there was an effect on the percentage of neutrophils (as a percentage of total nucleated cells) in the alveolar lavages on d 13, with a greater percentage of neutrophils in the Med and, to a lesser extent, high ammonia treatments than in the Con and low ammonia treatments. There was no difference between ammonia treatments in the 28 $\mathrm{d}$ postexperiment BAL number of red cells and nucleated cells, and there was also no difference between the values immediately after the steers left the climate chamber and those collected $28 \mathrm{~d}$ later ( $t$-values ranged from 1.36 to 0.94 ; $P$-values ranged from 0.19 to 0.77 ). The effect of ammonia treatment on BAL neutrophil percentages at d 13 was no longer present $28 \mathrm{~d}$ posttreatment $(P>0.05)$.

\section{$B W$ and Feed and Water Consumption}

There was no effect of ammonia treatment on BW of the steers at the end of treatment $(392 \pm 6 \mathrm{~kg}, P=$ $0.64)$ or $28 \mathrm{~d}$ postexperiment $(411 \pm 7 \mathrm{~kg}, P=0.91)$. Dry matter intake was reduced in the low ammonia treatment $(5.5 \pm 0.2 \mathrm{~kg})$, compared with the high $(6.5$ $\left.\pm 0.1 \mathrm{~kg} ; t_{71}=-4.60, P=0.003\right)$, Con $(6.4 \pm 0.1 \mathrm{~kg})$, and Med $(6.4 \pm 0.1 \mathrm{~kg})$ treatments. Dry matter intake did not change during the $12 \mathrm{~d}$ in the chambers $(P=$ $0.14)$, but water consumption increased $(P=0.02$; Figure 3$)$. Ammonia had no effect on water consumption $($ Con $=27.5 \pm 1.8 \mathrm{~L}$; low: $24.7 \pm 0.9 \mathrm{~L}$; Med: $27.9 \pm$ $1.6 \mathrm{~L}$; high: $26.4 \pm 1.0 \mathrm{~L}, P=0.19)$.

\section{Behavior}

Steers spent more time standing, as opposed to lying, in the 3 treatments exposed to $\mathrm{NH}_{3}$ than in the Con

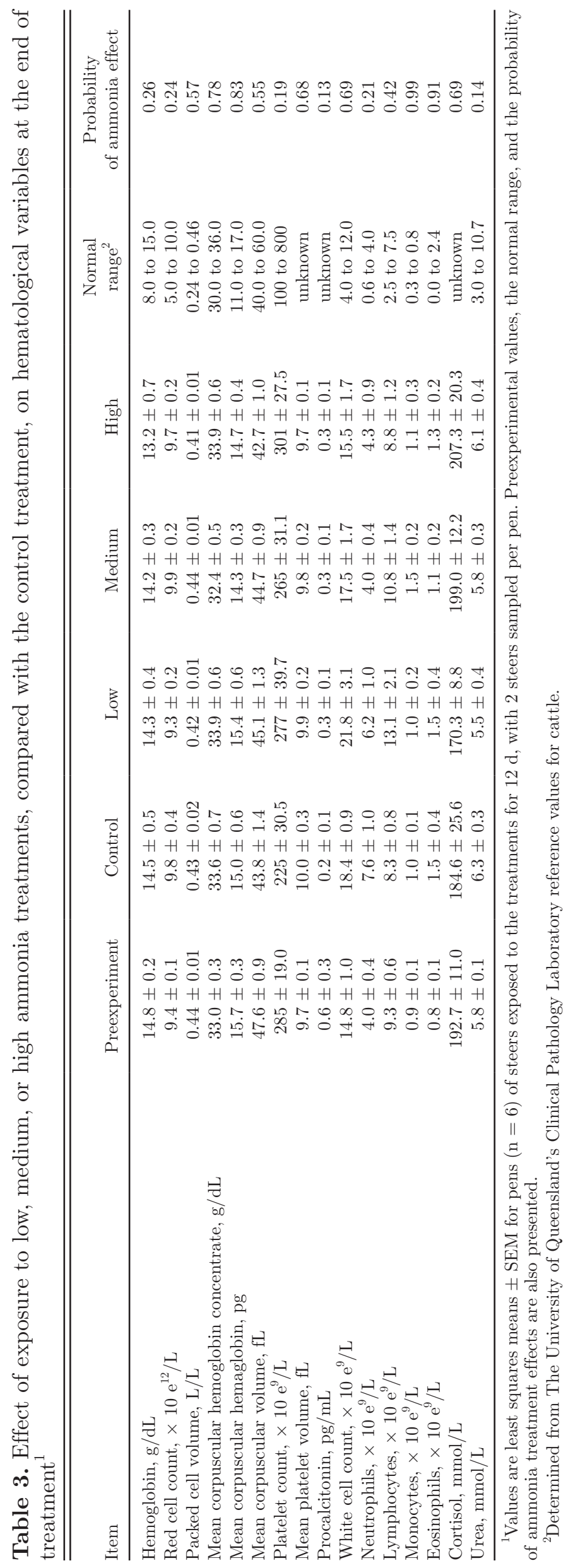



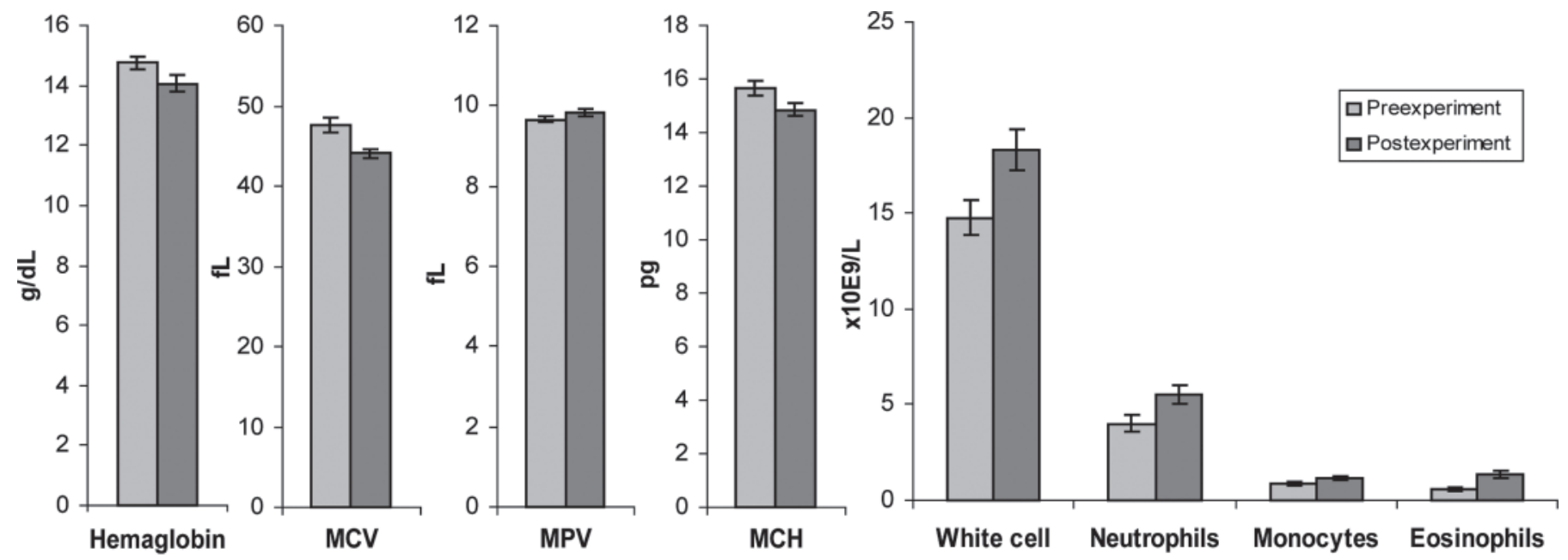

Hematological variable

Figure 1. Difference between preexperimental (light gray columns) and d 13 (d 0 postexperiment; dark gray columns) values of the hematological variables. $\mathrm{MCV}=$ mean corpuscular volume; $\mathrm{MPV}=$ mean platelet volume; $\mathrm{MCH}=$ mean corpuscular hemaglobin. Values are least squares means \pm SEM for pens $(n=6)$ of steers exposed to the treatments for $12 \mathrm{~d}$, with 2 steers sampled per pen.

treatment. Over the course of treatment, the time spent standing decreased from $87 \%$ on d 1 to approximately $70 \%$ on d 12 (Figure 4). Conversely, time spent lying increased from 13 to $30 \%$ over the same period. The proportion of steers panting was not affected $(P=0.47)$ by ammonia treatment, but it increased over the duration of each period, in particular on d 6 when the $\mathrm{T}_{\mathrm{DB}}$ increased from 30 to $31^{\circ} \mathrm{C}$ (Figure 5). All steers were panting by $\mathrm{d} 11$. The frequency of coughing was minimal but was increased $(P=0.07)$ in direct proportion to the $\mathrm{NH}_{3}$ concentration (Table 5). Lacrimation was increased $(P=0.001)$ by $\mathrm{NH}_{3}$, particularly in the high treatment. Coughing and lacrimation did not change over the duration of the experiment. Compared with the Con, the proportion of steers with nasal discharge was increased by $\mathrm{NH}_{3}$ in the low and Med treatments and was greatest for steers in the high treatment $(P$ $=0.001$; Table 5 ). The proportion of steers with nasal discharge increased during the $12 \mathrm{~d}$ the steers were in the climate chamber from 8 to $40 \%(P=0.01$; Figure $6)$. Neither ammonia treatment nor time spent in the climate chamber affected the number of bouts of licking, scratching, locomotion, and time spent ruminating and standing with the head down $(P>0.05)$.

\section{DISCUSSION}

The distal airway mucus absorbs most inhaled ammonia and partially protects the lungs (Schaerdel et al., 1983; Gustin et al., 1994). However, a fraction of inhaled $\mathrm{NH}_{3}$ can still reach the pulmonary parenchyma and, dependent on the concentration, cause local damage (World Health Organisation, 1986). Macrophages and neutrophils are white blood cells that form part of the immune response of the lungs by engulfing and destroying cellular debris, pathogens, and excess secretions (Quinn et al., 2002). Neutrophils are short lived, but respond rapidly to invading microorganisms. Macrophages are long lived and slow acting, but are able to initiate specific immune responses and secrete cytokines to activate lymphocytes and promote inflammatory responses (Quinn et al., 2002). It is therefore likely that measurable changes to these neutrophils and macrophages will occur in an irritated lung. In our experiment, after exposure of the cattle to $\mathrm{NH}_{3}$ in the low, Med, and high treatments, we saw an increase in BAL macrophage cytoplasmic abundance and vacuolation, indicating that the $\mathrm{NH}_{3}$ was irritating the lungs and causing an increase in pulmonary airway secretions. In

Table 4. Effect of exposure to low, medium, and high ammonia treatments, compared with the control treatment, on cellular concentrations in the bronchoalveolar lavages at the end of treatment ${ }^{1}$

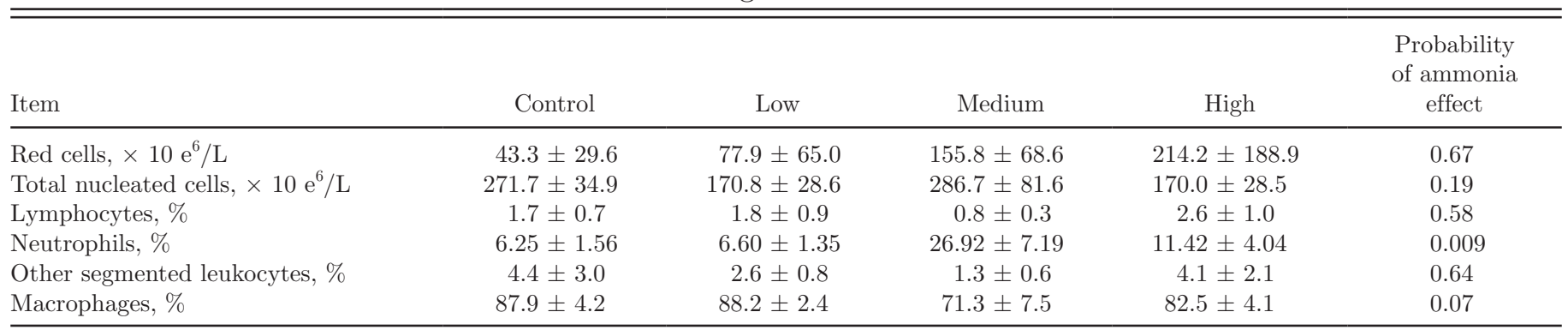

\footnotetext{
${ }^{1}$ Values are least squares means \pm SEM for pens $(n=6)$ of steers exposed to the treatments for $12 \mathrm{~d}$, with 2 steers sampled per pen.
} 


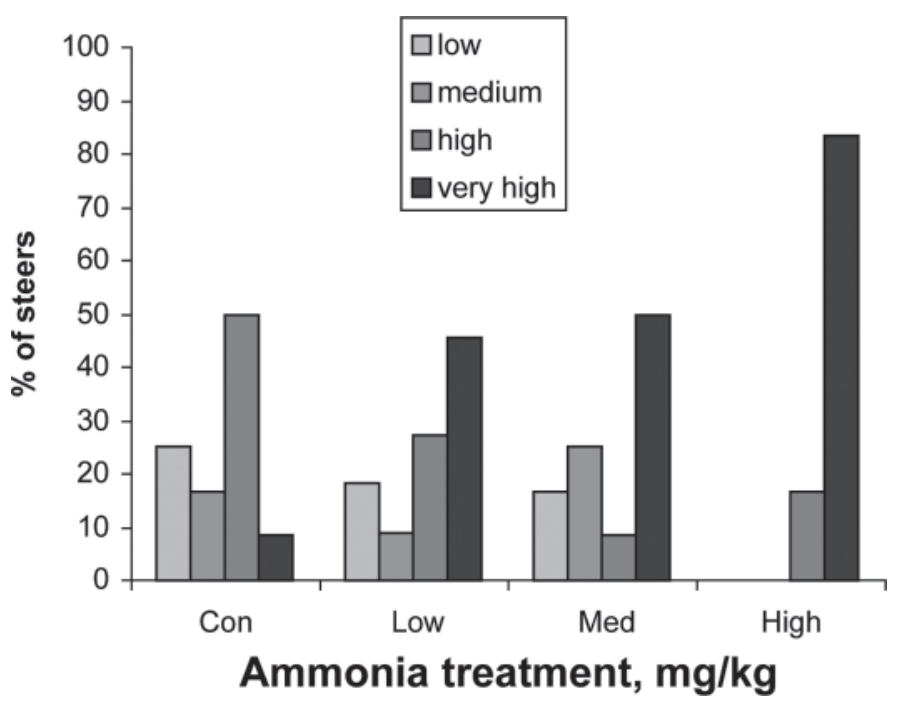

Figure 2. Effect of exposure to low, medium (Med), or high ammonia treatments, compared with a control (Con) treatment, on the proportion of steers with low, medium, high, and very high levels of pulmonary macrophage activity in the bronchoalveolar lavage taken on d 13. Values are least squares means percentage of steers for pens $(\mathrm{n}=6)$ exposed to the treatments for $12 \mathrm{~d}$, with 2 steers sampled per pen.

the Med and high treatments, increased neutrophils were present, indicating increased recruitment and active inflammation secondary to irritation by the ammonia. The percentage of neutrophils in the Med and high treatments are at quantities usually considered to be clinically indicative of active inflammation (McGuire and Babiuk, 1984; Caswell et al., 1998; Soethout et al., 2002). Respiratory disease in cattle is well described and often associated with sustained and pronounced neutrophil migration into lung tissue (Caswell et al., 1998; Ackermann et al., 1999; Soethout et al., 2002). Bronchoalveolar lavage cell population in normal calves in a study by McGuire and Babiuk (1984) was found to consist predominantly of mononuclear phagocytes ( $81 \%$ macrophages, $16 \%$ monocytes) and only $2 \%$ lymphocytes and $2 \%$ neutrophils; however, subsequent exposure to a bacterial pathogen caused a rapid influx of neutrophils. Increased BAL neutrophil percentage (from a 5\% baseline) is typical of bacterial infections but may also be observed due to noninfectious causes, such as neoplasia or foreign body reactions in domestic species (Raskin and Meyer, 2001). Our Con animals had a mean neutrophil percentage of 6.2 on d 0 posttreatment, whereas those in the Med and high treatments had neutrophil percentages of 27 and 11, respectively.

Neutrophil count has been shown to have a positive linear relationship with $\mathrm{NH}_{3}$ (at concentrations of 8 , $16,32,56$, and $75 \mathrm{mg} / \mathrm{m}^{3}$ ) in nasal lavages from pigs (Urbain et al., 1994). In our experiment, the neutrophil percentages at 23 and $34 \mathrm{mg} / \mathrm{m}^{3}$ were clinically indicative of active inflammation, although neutrophils at 34 $\mathrm{mg} / \mathrm{m}^{3}$ tended to be less than those at $23 \mathrm{mg} / \mathrm{m}^{3}$. This decline may indicate that at greater concentrations irritant gases caused local immunosuppression and a reduction in inflammatory cell number. Research on the

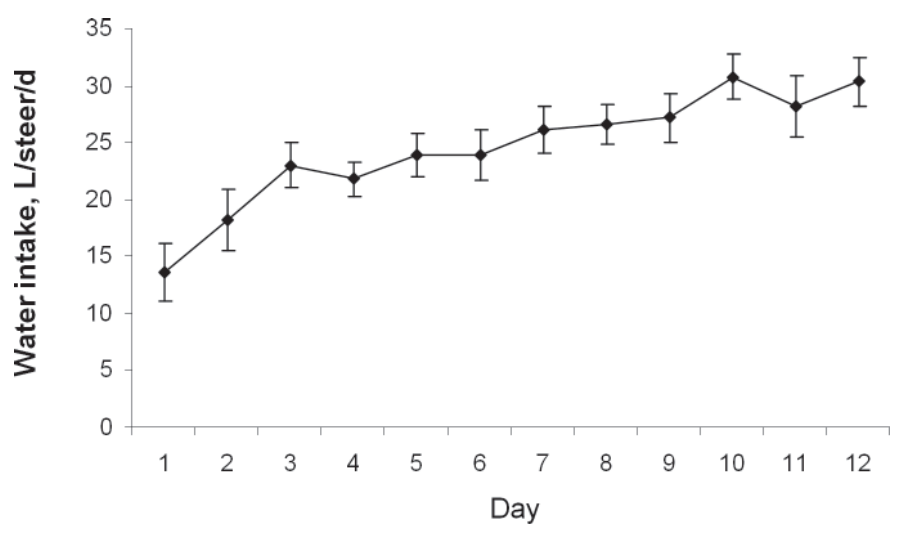

Figure 3. Water consumption $( \pm$ SEM) by steers (L/d) during the $12 \mathrm{~d}$ in the chambers. Values are least squares means and SEM for pens $(\mathrm{n}=6)$ each containing 3 steers exposed to the treatments for $12 \mathrm{~d}$.

dose-dependent necrosis of human alveolar macrophages by acrolein, an irritant gas, supports this suggestion (Li et al., 1997).

Bronchoalveolar lavages conducted $28 \mathrm{~d}$ after the animals left the chambers were used to assess recovery in the animals. Results showed no difference between the $\mathrm{NH}_{3}$ treatments for any of the cell counts. More importantly, macrophage activity was medium to low and neutrophil percentages within normal range, indicating that there were no long-term adverse effects from the ammonia exposure.

There were clear clinical signs that irritation to the eyes, nose, and lungs of the steers increased with $\mathrm{NH}_{3}$ concentration. Forty percent of the steers exposed to $34 \mathrm{mg} / \mathrm{m}^{3}$ had nasal discharges compared with $20 \%$ in the 11 and $23 \mathrm{mg} / \mathrm{m}^{3}$ treatments and $8 \%$ in the Con treatment. Similarly, $35 \%$ of the steers in the $34 \mathrm{mg} / \mathrm{m}^{3}$ ammonia treatment had excess lacrimation compared with approximately $10 \%$ in the 3 smaller concentrations. Steers exposed to 23 and $34 \mathrm{mg} / \mathrm{m}^{3}$ of ammonia coughed more, albeit in small numbers, than those in the Con and the $11 \mathrm{mg} / \mathrm{m}^{3}$ ammonia treatments. Evidently the Med and high treatments were more noxious than the smaller $\mathrm{NH}_{3}$ concentrations. Eye, nose, and

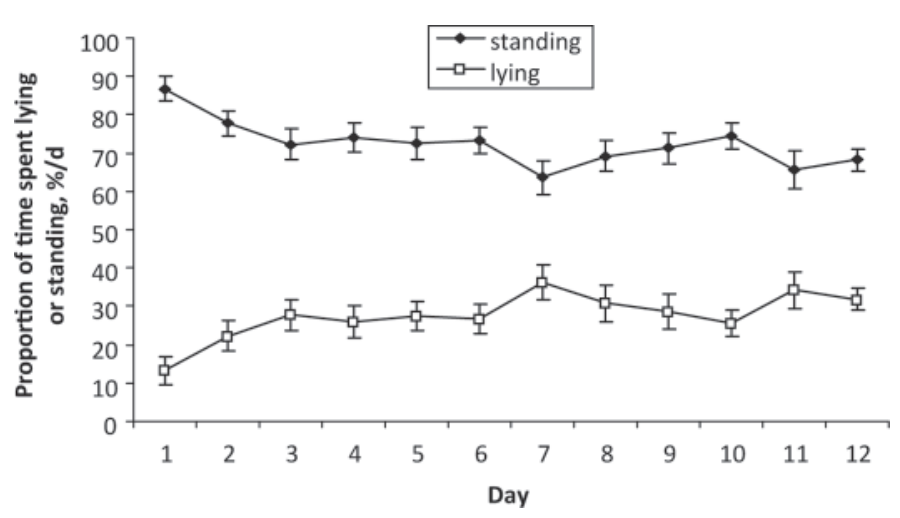

Figure 4. Proportion of time $( \pm \mathrm{SEM})$ steers spent standing and lying during the $12 \mathrm{~d}$ in the chambers. Values are least squares means and SEM for pens $(n=6)$ each containing 3 steers exposed to the treatments for $12 \mathrm{~d}$. 


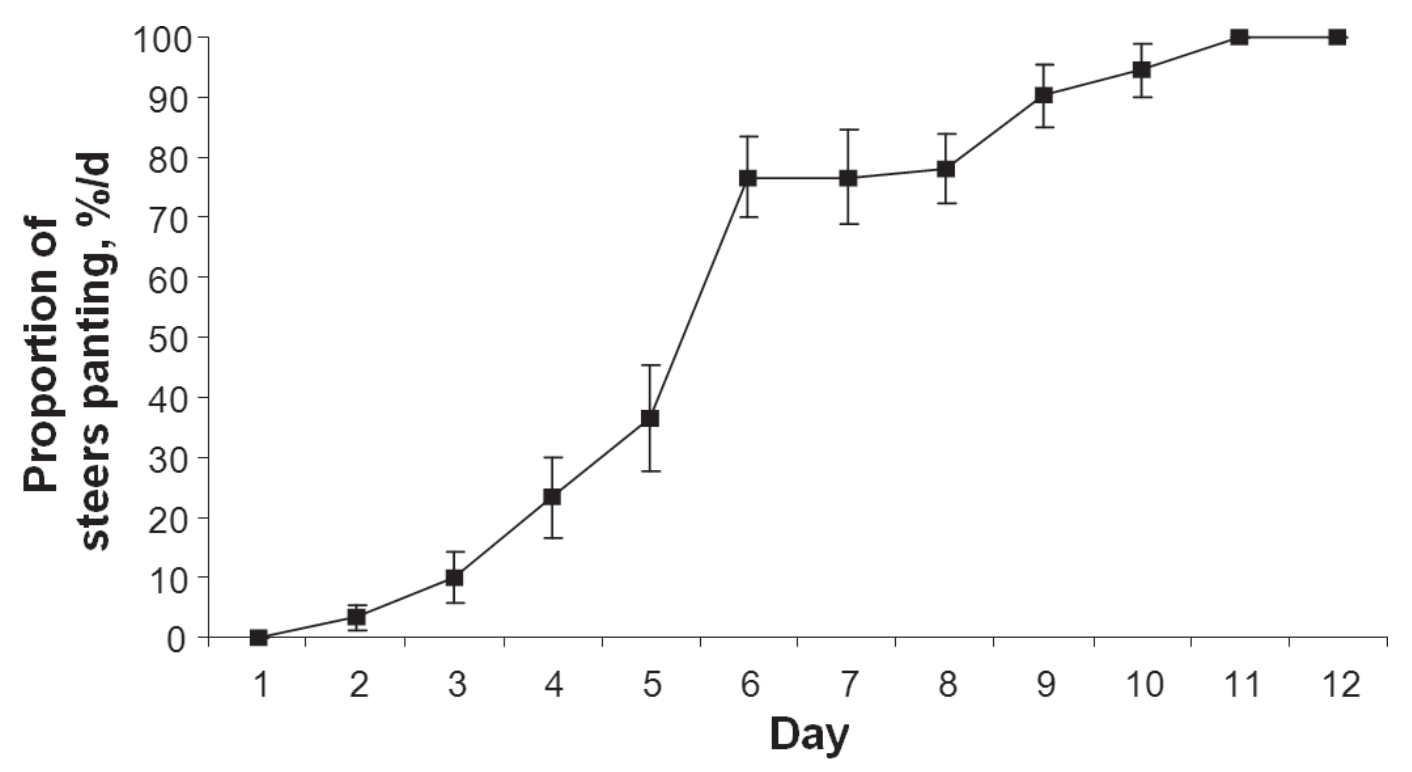

\begin{tabular}{|l|l|l|l|l|l|l|l|l|l|l|l|l|}
\hline $\mathrm{T}_{\mathrm{DB}}{ }^{\circ} \mathrm{C}$ & 26 & 27 & 28 & 29 & 30 & 31 & 31 & 31 & 32 & 33 & 34 & 35 \\
\hline $\mathrm{T}_{\mathrm{WB}}{ }^{\circ} \mathrm{C}$ & 23 & 24 & 25 & 25 & 26 & 26 & 27 & 27 & 27 & 28 & 28 & 29 \\
\hline
\end{tabular}

Figure 5. Proportion of steers $( \pm \mathrm{SEM})$ spent panting during the $12 \mathrm{~d}$ in the chambers and the corresponding dry bulb temperature ( $\left.\mathrm{T}_{\mathrm{DB}}\right)$ and wet bulb temperature $\left(\mathrm{T}_{\mathrm{WB}}\right)$. Panting values are least squares means and SEM for pens $(\mathrm{n}=6)$ each containing 3 steers exposed to the treatments for $12 \mathrm{~d}$.

throat irritation has also been reported in humans after exposure to a range of ammonia concentrations for 6 h/d over a 6-wk period (Ferguson et al., 1977); irritation at 38 and $75 \mathrm{mg} / \mathrm{m}^{3}$ ammonia was transient with acclimation occurring after 2 to 3 wk. If similar results were found in cattle, this would only be of relevance to some of the longest ship journeys. Severe coughing and profuse lacrimation and nasal discharge has been reported in lambs exposed to $56 \mathrm{mg} / \mathrm{m}^{3}$ ammonia for 28 d (Drummond et al., 1976); however, Gustin et al. (1994) reported no coughing, nasal discharge, or sneezing in pigs exposed for $6 \mathrm{~d}$ to $0,18,38$, and $75 \mathrm{mg} / \mathrm{m}^{3}$ of ammonia.
The percentage of cattle panting increased over the $12 \mathrm{~d}$, which was expected given that $\mathrm{T}_{\mathrm{DB}}$ and $\mathrm{T}_{\mathrm{WB}}$ also increased over this period. Similarly, the increase in water consumption over the $12 \mathrm{~d}$ is likely to be due to the increasing temperature, as has been reported by Beatty et al. (2006) in their study of the response of cattle to heat stress. Although there is only limited evidence that $\mathrm{NH}_{3}$ will predispose animals to increased temperature stress (Johnson et al., 1991), the converse clearly applies. At high temperatures, more $\mathrm{NH}_{3}$ is liberated into the environment and the 2 stresses can therefore be expected to act synergistically as stressors of cattle. The observed inflammation responses in cattle exposed

Table 5. Effect of exposure to low, medium, or high ammonia treatments, compared with the control treatment, on steer behavior ${ }^{1}$

\begin{tabular}{|c|c|c|c|c|c|c|}
\hline Behavior & Control & Low & Medium & High & SEM & $\begin{array}{c}\text { Probability } \\
\text { of ammonia } \\
\text { effect }\end{array}$ \\
\hline Panting, $\%$ of steers & 60.8 & 53.7 & 59.7 & 55.1 & 6.22 & 0.47 \\
\hline Coughing, No./30 min & 0.05 & 0.08 & 0.38 & 0.42 & 0.068 & 0.007 \\
\hline Excess lacrimation, $\%$ of steers & 8.3 & 11.1 & 10.6 & 36.1 & 7.23 & 0.001 \\
\hline Scratching, No. of bouts & 1.8 & 2.2 & 2.3 & 2.1 & 0.424 & 0.97 \\
\hline Locomotion, No. of bouts & 7.8 & 11.6 & 8.8 & 8.1 & 1.84 & 0.68 \\
\hline Ruminating, \% steers & 2.3 & 2.1 & 2.6 & 3.3 & 0.636 & 0.76 \\
\hline Head down, $\%$ steers & 26.6 & 26.3 & 24.9 & 26.3 & 5.06 & 0.08 \\
\hline
\end{tabular}

\footnotetext{
${ }^{1}$ Values are least squares means and SEM for pens $(n=6)$ each containing 3 steers exposed to the treatments for $12 \mathrm{~d}$.
} 


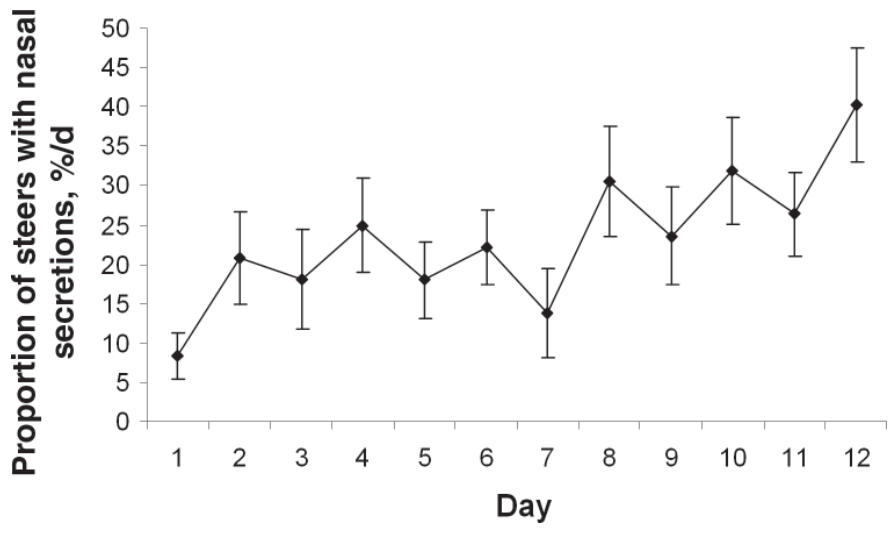

Figure 6. Proportion of steers $( \pm \mathrm{SEM})$ with nasal discharge during the $12 \mathrm{~d}$ in the chambers. Values are least squares means and SEM for pens $(n=6)$ each containing 3 steers exposed to the treatments for $12 \mathrm{~d}$.

to $\mathrm{NH}_{3}$ may make them more susceptible to disease, as has been observed in salmon with smaller concentrations of dissolved $\mathrm{NH}_{3}$ in their environment (Ackerman et al., 2006).

Ammonia concentration had no effect on any of the blood variables measured immediately after the animals left the climate chamber. However, there were some differences between the preexperiment and d 0 postexperiment concentrations of particular blood variables, with hemoglobin, mean corpuscular volume, and mean corpuscular hemoglobin decreased and mean platelet volume, total white cell count, neutrophils, eosinophils, and monocytes increased. Of these, only the total white cells, neutrophils, and monocytes were outside the normal ranges. Lymphocyte counts were slightly above the normal range both pre- and on d 0 postexperiment. In the week before entering the climate chamber, cattle were vaccinated for bovine ephemeral fever (3 d sickness), and it is possible that the increase in the white blood cells may have been associated with the immune response of the animal to the vaccination.

The steers spent more time standing in the $\mathrm{NH}_{3}$ treatments compared with Con, perhaps because they had excreta covering the floor and the Con did not (the latter was cleaned 3 times/d to reduce ammonia). Cattle avoid floors contaminated with fecal matter (Phillips and Morris, 2002), which probably encouraged them to stand rather than lie on the floor. The increase in lying time and decrease in standing time may indicate that cattle settled into the environment and were less stressed as the treatment proceeded. Reductions in physiological stress indicators after the first few days of the voyage have recently been recorded in cattle live export shipments from Ireland (McDonnell, 2010).

\section{Setting a Critical Limit for Ammonia on Cattle Ships}

When considering the establishment of critical limits for ammonia concentration on live export vessels, animals could be protected by a no observable adverse effect level (NOAEL) or a critical exposure limit (CEL). A NOAEL is an exposure level at which there is no statistically or biologically significant increase in the frequency or severity of adverse effects between the exposed population and its appropriate control; some effects may be produced at this level, but they are not considered as adverse, or as precursors to adverse effects. A CEL is a maximum daily exposure to a specific substance allowed over an 8-h shift, based on a TWA or the maximum exposure limit prescribed by regulation. The former is not appropriate because exposure to ammonia on ships is not at toxic concentrations, where adverse effects are evident. Critical exposure limits are more appropriate and could theoretically be based on the 3 Australian exposure standards for humans (NOHSC, 1995): the TWA is $19 \mathrm{mg} / \mathrm{m}^{3}$ over an 8-h period; the short-term exposure limit is $15 \mathrm{~min}$ of exposure to $26 \mathrm{mg} / \mathrm{m}^{3}$, which can be repeated 4 times per day; the final concentration is the permissible limit for any exposure, which is set at $38 \mathrm{mg} / \mathrm{m}^{3}$. These standards are not fine dividing lines between safe and unsafe concentrations, but represents gaseous concentrations of $\mathrm{NH}_{3}$ that should neither impair the health of, nor cause undue discomfort to, humans (NOHSC, 1995). Costa et al. (2003) recommended that the Australian cattle export industry adopt $19 \mathrm{mg} / \mathrm{m}^{3}$ as a critical concentration for gaseous $\mathrm{NH}_{3}$ to match the TWA for humans; however, they found some evidence of increased pulmonary inflammation in cattle exposed to $17 \mathrm{mg} / \mathrm{m}^{3}$ of $\mathrm{NH}_{3}$ for $6 \mathrm{~d}$. This anomaly may be because NOHSC exposure standards are designed for intermittent exposure, whereas livestock aboard live export vessels are constantly exposed to ammonia. Therefore, it is not considered appropriate to set critical concentrations for livestock based on human standards.

Few ammonia standards are available for livestock housing. The European standard for pig housing is 15 $\mathrm{mg} / \mathrm{m}^{3}$, measured as a mean in the dwelling zone (Commission Internationale de Génie Rural, 1984). Urbain et al. (1994) recommended that the NOAEL of $\mathrm{NH}_{3}$ for pigs is probably about $11 \mathrm{mg} / \mathrm{m}^{3}$, after finding inflammatory responses in pigs housed in $19 \mathrm{mg} / \mathrm{m}^{3}$. However, NOAEL are usually derived from the least observed adverse effect level (LOAEL) and cumulative uncertainty factors that are included to protect every individual. For example, the US Agency for Toxic Substances and Disease Registry has derived an acute-duration inhalation minimal risk level for ammonia of $1.3 \mathrm{mg} / \mathrm{m}^{3}$, based on a LOAEL of $38 \mathrm{mg} / \mathrm{m}^{3}$ for eye, nose, and throat irritation in a study with volunteers (Agency for Toxic Substances and Disease Registry, 2006). This was derived as 38 divided by an uncertainty factor of 30 (3 for the use of a minimal LOAEL $\times 10$ to protect sensitive individuals). A NOAEL derived from our study, based on pulmonary macrophage activity, would be less than $11 \mathrm{mg} / \mathrm{m}^{3}$, the LOAEL in our study. The uncertainty factors would be differences between individuals (divide by 10), subchronic rather than chronic exposure 
(divide by 3 ), knowledge of the LOAEL, rather than NOAEL (multiply by 10), or 300 in total. Thus a concentration of $11 / 300$ or $0.04 \mathrm{mg} / \mathrm{m}^{3}$ would be expected to protect all individuals. However, NOAEL are usually established to protect humans from acute exposure, not the chronic exposure to which livestock are exposed on live export vessels (Collins et al., 2004), and the rationale for implementing them to protect animals has not yet been established.

Most current exposure standards do not represent no-effect levels that guarantee protection to every individual; rather, they are indicative of where and when appropriate control measures are required (Costa et al., 2003). Establishing a CEL in subclinically affected animals should take into account the proportion of animals experiencing prolonged physiological disturbances and more mild problems, such as irritation. In humans, the proportion reporting unpleasant sensory stimulation is additionally considered, and this could be estimated using avoidance or other tests indicating cognitive responses to ammonia, but such investigations do not appear to have been conducted in cattle.

The results from the current study demonstrate that the effects on pathophysiology are transitory, but clearly $\mathrm{NH}_{3}$ caused temporary discomfort (irritation and inflammation), as evidenced by increased lacrimation, nasal discharge, and coughing. Active pulmonary inflammation is also evidence of reduced welfare. There were clinical and pathological differences between the Con and low treatments, between the low and Med treatments, and also the Med and high treatments. The magnitude of the differences in pulmonary macrophage activity, lacrimation, and nasal discharge was much greater between the Med and high treatments. However, the magnitude of the differences in BAL neutrophils and coughing was most marked between the low and Med treatments. Therefore, our results support the adoption of a concentration of less than $23 \mathrm{mg} /$ $\mathrm{m}^{3}$, which strengthens the recommendation of a level of $19 \mathrm{mg} / \mathrm{m}^{3}$ by Costa et al. (2003), as a CEL (not a NOAEL). The critical duration of exposure should be sufficient to cause the irritation/inflammation, but this is less relevant to animals than humans, who usually have transient exposure, and is difficult to measure compared with an instantaneous recording of ammonia concentration. The CEL for cattle on ships should therefore not be time dependent.

The response of the cattle to the different $\mathrm{NH}_{3}$ concentrations was only seen in a proportion of the animals. For example, approximately 35 to $40 \%$ of the steers exposed to the high treatment had excess lacrimation and nasal discharge, as opposed to 10 to $20 \%$ in the low and Med treatments and $8 \%$ in the Con treatment. At what percentage of animals affected does a limit become critical? Paustenbach and Gaffney (2006) have considered this question in relation to human exposure to odors and recommend that most individuals (which they suggest might be 80 to $95 \%$ ) should be protected from irritation or unpleasant sensory stimulation. By this crite- rion, the percentage of steers with nasal discharges was just acceptable in the low and Med treatments, but was unacceptable in the high treatment, being 41\%. Similarly, the percentage of steers lacrimating excessively was too large $(36 \%)$ in the high treatment, but was acceptable in the other treatments. Hence, in relation to irritation, $34 \mathrm{mg} / \mathrm{m}^{3}$ of exposure is too great, but 23 $\mathrm{mg} / \mathrm{m}^{3}$ is acceptable. However, the pulmonary inflammatory responses and coughing indicate that $23 \mathrm{mg} /$ $\mathrm{m}^{3}$ is also too great and that a value less than $23 \mathrm{mg} /$ $\mathrm{m}^{3}$ should be a CEL for $\mathrm{NH}_{3}$ exposure for cattle. In the absence of further research to identify the appropriate concentration more precisely, we support the $19 \mathrm{mg} / \mathrm{m}^{3}$ concentration recommended by Costa et al. (2003).

We conclude that $\mathrm{NH}_{3}$ concentrations from 11 to 34 $\mathrm{mg} / \mathrm{m}^{3}$ had a measurable influence on the physiology of cattle, but there was no evidence of long-term, adverse responses. Hematological variables were not affected by ammonia. There was evidence that ammonia irritated the upper and lower respiratory tract and the eyes of the cattle. The proportion of cattle experiencing irritation at the $34 \mathrm{mg} / \mathrm{m}^{3}$ was greater than the recommended maximum proportion of humans experiencing irritation as a result of exposure to noxious odors (5 to $20 \%$ ). On exposure to 11 to $23 \mathrm{mg} / \mathrm{m}^{3}$ of ammonia, the proportion of steers with nasal discharge and excessive lacrimation (10 to 20\%) was acceptable by proposed criteria for humans, whereas it was unacceptable at 34 $\mathrm{mg} / \mathrm{m}^{3}$ (35 to $40 \%$ ). There was increased coughing and significant inflammatory cell numbers in bronchoalveolar fluid at $23 \mathrm{mg} / \mathrm{m}^{3}$, as well as increased pulmonary macrophage activity at 11,23 , and $34 \mathrm{mg} / \mathrm{m}^{3}$. Hence, by these criteria, we recommend that the critical exposure limit for steers should be less than $23 \mathrm{mg} / \mathrm{m}^{3}$, and in the absence of further research, we support the previously proposed limit of $19 \mathrm{mg} / \mathrm{m}^{3}$.

\section{LITERATURE CITED}

Ackerman, P. A., B. J. Wicks, and G. K. Iwama. 2006. Low levels of environmental ammonia increase susceptibility to disease in Chinook salmon smolts. Physiol. Biochem. Zool. 79:695-707.

Ackermann, M. R., K. A. Brogden, A. F. Florance, and M. E. Kehrli Jr. 1999. Induction of CD18-mediated passage of neutrophils by Pasteurella haemolytica in pulmonary bronchi and bronchioles. Infect. Immun. 67:659-663.

Agency for Toxic Substances and Disease Registry (ATSR). 2006. Ammonia, Regulations and Advisories. 2006. Accessed Dec. 20, 2009. http://www.atsdr.cdc.gov/toxprofiles/tp126-c8.pdf.

Australian Standards for the Export of Livestock (ASEL). 2006. Version 2.1. Australian Department of Agriculture, Fisheries and Forestry, Canberra.

Beatty, D. T., A. Barnes, E. Taylor, E. Pethick, M. McCarthy, and S. K. Maloney. 2006. Physiological responses of Bos taurus and Bos indicus cattle to prolonged, continuous heat and humidity. J. Anim. Sci. 84:972-985.

Caswell, J. L., D. M. Middleton, S. D. Sorden, and J. R. Gordon. 1998. Expression of the neutrophil chemoattractant interleukin-8 in the lesions of bovine pneumonic pasteurellosis. Vet. Pathol. 35:124-131.

Collins, J. F., G. V. Alexeeff, D. C. Lewis, D. E. Dodge, M. A. Marty, T. R. Parker, J. D. Budroe, R. H. F. Lam, M. J. Lipsett, J. R. Fowles, and R. Das. 2004. Development of acute inhala- 
tion reference exposure levels (RELs) to protect the public from predictable excursions of airborne toxicants. J. Appl. Toxicol. 24:155-166.

Commission Internationale de Génie Rural. 1984. Report of working group on climatization of animal houses. Scottish Farm Building Investigation Unit, Craibstone, Aberdeen.

Costa, N., J. Accloly, and M. Cake. 2003. Determining critical atmospheric ammonia levels for cattle, sheep and goats-A literature review. Meat Livest. Aust. Ltd., North Sydney, New South Wales.

Drummond, J. G., S. E. Curtis, J. M. Lewis, F. C. Hinds, and J. Simon. 1976. Exposure of lambs to atmospheric ammonia. J. Anim. Sci. 42:1343. (Abstr.)

Ferguson, W. S., W. C. Koch, L. B. Webster, and J. R. Gould. 1977. Human physiological response and adaptation to ammonia. J. Occup. Med. 16:646-655.

Gustin, P., B. Urbain, J.-F. Prouvost, and M. Ansay. 1994. Effects of atmospheric ammonia on pulmonary hemodynamics and vascular permeability in pigs: Interactions with endotoxins. Toxicol. Appl. Pharmacol. 125:17-26.

Harada, N., M. Fujii, and H. Dodo. 1983. Olfactory disorder in chemical plant workers exposed to $\mathrm{SO}_{2}$ and/or $\mathrm{NH}_{3}$. J. Sci. Labour 59:17-23.

Holness, D. L., J. T. Purdham, and J. R. Nethercott. 1989. Acute and chronic respiratory effects of occupational exposure to ammonia. Am. Ind. Hyg. Assoc. J. 50:646-650.

Johnson, R. W., S. E. Curtis, and R. D. Shanks. 1991. Effects on chick performance of ammonia and heat stressors in various combinations. Poult. Sci. 70:1132-1137.

Jones, J. B., C. M. Wathes, K. C. Persaud, R. P. White, and R. B. Jones. 2001. Acute and chronic exposure to ammonia and olfactory acuity for $n$-butonal in the pig. Appl. Anim. Behav. Sci. $71: 13-28$.

Kristensen, H. H., L. R. Burgess, T. G. H. Demmers, and C. M. Wathes. 2000. The preferences of laying hens for different concentrations of atmospheric ammonia. Appl. Anim. Behav. Sci. 68:307-318.

Kristensen, H. H., and C. M. Wathes. 2000. Ammonia and poultry welfare: A review. World's Poult. Sci. J. 56:235-245.

Li, L., R. F. Hamilton, D. E. Taylor, and A. Holian. 1997. Acroleininduced cell death in human alveolar macrophages. Toxicol. Appl. Pharmacol. 145:331-339.

MAMIC Pty. 2001. Investigation of the Ventilation Efficacy on Livestock Vessels. Internal Report. Meat Livest. Aust., Sydney, Australia.

McDonnell, B. 2010. Immunological, inflammatory and physiological responses of cattle during transportation and housing. MS Diss. Univ. College Dublin, Eire.

McGuire, R. L., and L. A. Babiuk. 1984. Evidence for defective neutrophil function in lungs of calves exposed to infectious bovine rhinotracheitis virus. Vet. Immunol. Immunopathol. $5: 259-271$.

National Occupational Health and Safety Commission (NOHSC). 1995. Exposure Standards for Atmospheric Contaminants in the Occupational Environment. NOHSC:1003. Aust. Gov. Publ. Serv., Canberra.

Paustenbach, D. J., and S. H. Gaffney. 2006. The role of odor and irritation in risk perception and the setting of occupational exposure limits. Int. Arch. Occup. Environ. Health 79:339-342.

Phillips, C. J. C. 2008. The welfare of livestock during sea transport. Pages 137-156 in Long Distance Transport and Welfare of Farm Animals. M. Appleby, V. Cussen, L. Garces, L. A. Lambert, and J. Turner, ed. CAB Int., Wallingford, UK.

Phillips, C. J. C., and I. D. Morris. 2002. The ability of cattle to distinguish between, and their preference for, floors with different levels of friction, and their avoidance of floors contaminated with excreta. Anim. Welf. 11:21-29.

Quinn, P. J., B. K. Markey, M. E. Carter, W. J. Donnelly, and F. C. Leonard. 2002. Veterinary Microbiology and Microbial Disease. Blackwell Sci., Oxford, UK.

Raskin, R. E., and D. J. Meyer. 2001. Atlas of Canine and Feline Cytology. 1st ed. WB Saunders Co., Philadelphia, PA.

Schaerdel, A. D., W. J. White, C. M. Lang, B. H. Dvorchick, and K. Bohner. 1983. Localized and systemic effects of environmental ammonia in rats. Lab. Anim. Sci. 33:40-45.

Schiffman, S. S. 1998. Livestock odors: Implications for human health and well-being. J. Anim. Sci. 76:1343-1355.

Soethout, E. C., K. E. Müller, and V. P. Rutten. 2002. Neutrophil migration in the lung, general and bovine-specific aspects. Vet. Immunol. Immunopathol. 87:277-285.

Tripp, K. M., J. P. Verstegen, C. J. Deutsch, R. K. Bonde, M. de Wit, C. A. Manire, J. Gaspard, and K. E. Harr. 2010. Evaluation of adrenocortical function in Florida manatees (Trichechus manatus). Zoo Biol. doi:10.1002/zoo.20311.

Tudor, G., J. Accioly, D. Pethick, N. Costa, E. Taylor, and C. White. 2003. Decreasing shipboard ammonia levels by optimising the nutritional performance of cattle and the environment on ship during live export. Meat \& Livestock Australia, North Sydney, New South Wales, Australia.

Urbain, B., P. Gustin, J. F. Prouvost, and M. Ansay. 1994. Quantitative assessment of aerial ammonia toxicity to the nasal mucosa by the use of the nasal lavage method in pigs. Am. J. Vet. Res. 55:1335-1340.

Wathes, C. M., J. B. Jones, H. H. Kristensen, E. K. M. Jones, and A. J. F. Webster. 2002. Aversion of pigs and domestic fowl to atmospheric ammonia. Trans. ASAE 45:1605-1610.

World Health Organisation. 1986. Environmental Health, Criteria 54: Ammonia. World Health Organisation, Geneva, Switzerland. 